\title{
Morphine Sulfate and Naltrexone Hydrochloride Extended-Release Capsules: Naltrexone Release, Pharmacodynamics, and Tolerability
}

Franklin Johnson, $\mathrm{MS}^{1}$, and Beatrice Setnik, $\mathrm{PhD}^{2}$

\begin{abstract}
Background: Morphine sulfate and naltrexone hydrochloride extended-release capsules (EMBEDA,
From: ${ }^{2} \mathrm{Clin}$ Pharm PK Consulting LLC, Bridgewater,

NJ; ${ }^{2}$ Pfizer Inc, Cary, NC.

Mr. Johnson is with ClinPharm

PK Consulting LLC in Bridgewater, NJ.

Dr. Setnik is with Pfizer Inc of

Cary, NC

Address correspondence: Franklin Johnson ClinPharm PK Consulting LLC 625 Talamini Road

Bridgewater, NJ 08807 E-mail:

franklinkjohnson@yahoo.com

Disclaimer and Conflicts of interest: Please see page 404.

Manuscript received: 02/19/2011 Revised manuscript received: 05/19/2011

Accepted for publication: 05/25/2011

Free full manuscript: www.painphysicianjournal.com

King Pharmaceuticals, Inc., Bristol, TN), indicated for management of chronic, moderate-to-severe pain, contain pellets of extended-release morphine sulfate with a sequestered naltrexone core (MS-sNT). Taken as directed, morphine provides analgesia while naltrexone remains sequestered; if tampered with by crushing, naltrexone is released to mitigate morphine-induced euphoric effects. While it is necessary to establish that formulations intended to reduce attractiveness for abuse are successful in doing so, it is also necessary to demonstrate that product therapeutic integrity is maintained for patients.

Objectives: Data were reviewed from 3 studies to determine: 1) the quantity of naltrexone released when MS-sNT pellets are crushed (MS-sNTC) for at least 2 minutes with mortar and pestle); 2) the extent to which the naltrexone released upon crushing mitigated morphine-induced subjective effects; and 3) whether sequestered naltrexone precipitates opioid withdrawal when MSsNT is taken as directed.

Methods: The naltrexone bioavailability study compared naltrexone release from MS-sNTC with that from whole intact MS-sNT capsules (MS-sNTW) and an equal naltrexone solution (NS) dose. Equivalent bioavailability was established if $90 \%$ confidence intervals $(\mathrm{Cls})$ for geometric mean ratios (maximum plasma naltrexone concentration $\left[\mathrm{C}_{\max }\right.$ ] and area under the concentration-time curve extrapolated to infinity [AUC ] $^{\text {] }}$ ) fell between $80 \%$ and $125 \%$. The oral pharmacodynamic study assessed drug liking and euphoria and pharmacokinetic properties of MS-sNTC and MS-sNTW compared with morphine sulfate solution (MSS) and placebo. The 12-month, open-label (OL) safety study evaluated safety of MS-sNT administered orally as directed in patients with chronic, moderate-to-severe pain. Safety assessments included withdrawal symptoms based on the Clinical Opiate Withdrawal Scale (COWS).

Results: Naltrexone from MS-sNTC met criteria for equivalent bioavailability to NS. Although morphine relative bioavailability was similar for MS-sNTC and MSS, mean peak $\left(E_{\text {max }}\right.$ ) visual analog scale (VAS) scores for drug liking and Cole/Addiction Research Center Inventory Stimulation-Euphoria were significantly reduced for MS-sNTC vs MSS $(P<0.001)$. In these 2 studies, a total of 6 participants had one measurement of plasma naltrexone after MS-sNTW that was above the lower limit of quantification. In the OL safety study, $72 / 93$ participants (77\%) had no quantifiable naltrexone concentrations. There was neither evidence of naltrexone accumulation for any participant nor any significant correlation with MSsNT dose, age, or sex. Of 4 participants with the highest naltrexone concentrations, none had COWS scores consistent with moderate opioid withdrawal symptoms. Only 5 participants had COWS scores consistent with moderate opioid withdrawal; all 5 had not taken MS-sNT as directed.

Limitations: Study populations may not be fully representative of patients receiving opioid therapy for the management of chronic, moderate-to-severe pain and of opioid abusers.

Conclusions: When MS-sNT capsules are crushed, all of the sequestered naltrexone (relative to oral NS) is released and immediately available to mitigate morphine-induced effects. When MSsNT was crushed, the naltrexone released abated drug liking and euphoria relative to that from an equal dose of immediate-release morphine from MSS administration in a majority of participants. Naltrexone concentrations were low over a period of 12 months without evidence of accumulation, and there were no observable opioid withdrawal symptoms when MS-sNT was taken as directed.

Key words: Chronic pain, drug liking, euphoria, extended-release opioids, morphine, naltrexone, opioid withdrawal, pharmacodynamics, pharmacokinetics

Pain Physician 2011; 14:391-406
\end{abstract}




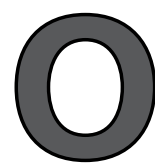

pioids play a role in the relief of chronic pain in carefully selected and monitored patients $(1,2)$. Extended-release opioid formulations provide effective analgesia with once- or twice-daily dosing and may be more suitable than immediaterelease formulations for patients with chronic, moderate-to-severe pain who require around-the-clock opioid therapy (3-7). The potential benefits anticipated from oral extended-release formulations include sustained, 12- to 24-hour pain relief; better nighttime pain control; reduced pill burden; increased compliance; and greater convenience compared with immediaterelease formulations requiring administration every 3 to 4 hours $(4,5,7,8)$.

Increased use of opioids has been accompanied by increased misuse, abuse, and diversion of these medications and has become a public health concern (9-14). While extended-release opioid formulations have the potential to improve pain management for many patients, their higher opioid content per dose may make them particularly appealing to abusers for tampering with to access the opioid and achieve a high $(8,12)$.

One of several pharmaceutical strategies suggested to address this problem is the inclusion of antagonists that are released upon product tampering to reduce the opioid-induced, euphoric effects sought by abusers $(8,15-19)$. Naltrexone is a potent, orally bioavailable mu-opioid receptor antagonist that has been used clinically to treat opioid dependence (20-23). Naltrexone $100 \mathrm{mg}$ administered 24 hours before, at the time of, and 24 hours after oral administration of morphine has also been used to block pharmacologic effects of morphine and allow bioequivalence studies to be safely conducted at doses of morphine as high as $200 \mathrm{mg}$ without the occurrence of serious side effects, such as respiratory depression (24).

Naltrexone administered orally is nearly completely absorbed from the gastrointestinal tract (22); however, it undergoes rapid and extensive first-pass metabolism to 6- $\beta$-naltrexol, limiting the amount of unchanged naltrexone reaching the systemic circulation and resulting in naltrexone oral bioavailability of $5 \%$ to $60 \%$ (25). Plasma concentrations of the metabolite are generally an order of magnitude greater than plasma naltrexone concentrations $(20,21,26,27)$; thus, pharmacokinetic studies measure both naltrexone and $6-\beta$-naltrexol plasma concentrations. However, $6-\beta$-naltrexol has opioid antagonist properties of $1 / 12$ th to $1 / 50$ th the potency of naltrexone $(20,26,27)$.
Morphine sulfate and naltrexone hydrochloride extended-release capsules (EMBEDA, King Pharmaceuticals, Inc., Bristol, TN), approved by the US Food and Drug Administration in August 2009 for the management of chronic, moderate-to-severe pain, contain pellets of extended-release morphine sulfate with a sequestered naltrexone core (MS-sNT) $(28,29)$. When MS-sNT is taken as directed, morphine is slowly released, reaching peak concentrations at approximately 8 hours post-dose, to provide analgesia for up to 24 hours; the naltrexone core of each pellet remains sequestered and is largely unabsorbed $(28,30,31)$. Conversely, immediate-release morphine sulfate reaches peak concentrations at approximately one hour post-dose and has a rapid terminal half-life of 4 hours $(32,33)$. Maximum plasma morphine concentrations after morphine sulfate solution (MSS) intake are 5-fold greater than those after MS-sNT taken whole as directed (32). However, the rapid elimination of immediate-release morphine renders its 4-hour effectiveness substantially shorter than that of extendedrelease formulations $(32,33)$.

While it is necessary to establish that new formulations (i.e. MS-sNT) that are intended to have reduced attractiveness for abuse are indeed successful in mitigating abuse, it is also necessary to demonstrate that the therapeutic integrity of the product is maintained for patients when it is taken as directed (17). Naltrexone should be released only upon tampering with MSsNT, and should be released in a sufficient amount to mitigate subjective morphine-induced effects. When MS-sNT is taken as directed, naltrexone should remain sequestered, with minimal effects on efficacy and safety. The purpose of this article is to review studies demonstrating that naltrexone in MS-sNT performs as intended.

\section{Objective}

This article reviews data from 3 studies, 2 in which pellets of MS-sNT were administered orally after crushing $(29,32)$ and one in which MS-sNT was taken as directed (34). These studies determined: 1) the quantity of naltrexone released when MS-sNT was crushed, relative to an oral solution of the same dose (29); 2) whether the dose of naltrexone released from the crushed MS-sNT was sufficient to mitigate morphineinduced subjective effects (32); and 3) whether sequestered naltrexone affected safety and the occurrence of withdrawal syndrome when MS-sNT was taken as directed (34). 


\section{Methods}

The details of the study designs, participants, treatments, and outcome measures have been published previously, are summarized in Table 1, and are briefly described here $(29,32,34)$. Each of these 3 studies was approved by a corresponding Institutional Review
Board. Study flow for the 3 studies is detailed in Table 2. In each study, the protocol and any amendments, consent forms, participant-related information, and recruitment were reviewed and approved by an institutional review board and all participants were provided written informed consent before study initiation $(29,32,34)$.

Table 1. Summary of study design, participants, treatments, and outcome measures.

\begin{tabular}{|c|c|c|c|}
\hline Study & $\begin{array}{c}\text { Naltrexone relative } \\
\text { bioavailability }(29,52)\end{array}$ & $\begin{array}{c}\text { Oral drug liking/euphoria } \\
(32,42)\end{array}$ & 12-Month safety $(34,40)$ \\
\hline $\begin{array}{l}\mathrm{N} \text { (enrolled/ } \\
\text { completed) }\end{array}$ & $24 / 23$ & $32 / 32$ & $\begin{array}{c}467 / 160 \\
(\mathrm{n}=93, \text { PK subset })\end{array}$ \\
\hline Design & $\begin{array}{l}\text { Randomized, 3-way, crossover, } \\
\text { single-dose, open-label }\end{array}$ & $\begin{array}{l}\text { Randomized, 4-way crossover, } \\
\text { double-blind, triple-dummy, } \\
\text { placebo-controlled }\end{array}$ & Open-label \\
\hline Phase & I & I & III \\
\hline Study dates & February 12, 2007 to March 19, 2007 & March 2, 2007 to May 28, 2007 & December 7, 2006 to March 7, 2008 \\
\hline Participants & $\begin{array}{l}\text { Healthy volunteers aged } \\
18 \text { to } 55 \text { years }\end{array}$ & $\begin{array}{l}\text { Nondependent, recreational } \\
\text { opioid users aged } 18 \text { to } 55 \text { years }\end{array}$ & $\begin{array}{l}\text { Patients with chronic pain lasting } \\
\text { for } 3 \text { months or more; aged } 18 \text { to } \\
70 \text { years; patients could have liver } \\
\text { function test results up to, but not } \\
\text { including, 3x ULN }\end{array}$ \\
\hline Treatments (oral) & $\begin{array}{l}\text { - Crushed pellets from } 1 \mathrm{MS} \text {-sNT } \\
\text { 60-mg capsule (MS-sNTC) } \\
\text { - One intact MS-sNT 60-mg capsule } \\
\text { (MS-sNTW) } \\
\text { - NS at dose (2.4 mg) equivalent } \\
\text { to that in } 1 \mathrm{MS} \text {-sNT capsule }\end{array}$ & $\begin{array}{l}\text { - Crushed pellets from } 2 \text { MS-sNT } \\
\text { 60-mg capsules (MS-sNTC) } \\
\text { - Two intact MS-sNT 60-mg capsules } \\
\text { (MS-sNTW) } \\
\text { - MSS, } 120 \mathrm{mg} \\
\text { - Placebo }\end{array}$ & $\begin{array}{l}\text { - MS-sNT capsules titrated to effec- } \\
\text { tive dose (median average daily } \\
\text { dose } 58.6 \mathrm{mg} \text { ), with adjustments } \\
\text { as clinically indicated throughout } \\
\text { study; treatment continued for up to } \\
12 \text { months }\end{array}$ \\
\hline $\begin{array}{l}\text { Key outcome } \\
\text { measures }\end{array}$ & $\begin{array}{l}\text { - Plasma naltrexone and } \\
\text { 6- } \beta \text {-naltrexol PK measures: } \\
\mathrm{C}_{\max }, \mathrm{T}_{\max }, \mathrm{AUC}_{\text {last }}, \text { and } \mathrm{AUC}_{\infty}\end{array}$ & $\begin{array}{l}\text { - VAS scores: } \\
\text { Drug liking } \\
\text { High } \\
\text { Good effects } \\
\text { Bad effects } \\
\text { Feel sick } \\
\text { Nausea } \\
\text { - Cole/ARCI scores: } \\
\text { Stimulation-Euphoria }{ }^{\mathrm{a}} \\
\text { Abuse potential }^{\mathrm{a}} \\
\text { Unpleasantness-dysphoria } \\
\text { Unpleasantness-physical } \\
\text { - ARCI scores: } \\
\text { MBG } \\
\text { LSD } \\
\text { - Subjective drug value }{ }^{\mathrm{a}} \text { (\$Can) } \\
\text { - Plasma morphine, naltrexone, and } \\
\text { 6- } \beta \text {-naltrexol PK measures }\end{array}$ & $\begin{array}{l}\text { - Safety } \\
\text { - Plasma morphine, naltrexone, and } \\
6 \text { - } \beta \text {-naltrexol PK measures in a } \\
\text { subset of patients }\end{array}$ \\
\hline
\end{tabular}

\section{aPrimary measures.}

$\mathrm{ARCI}=$ Addiction Research Center Inventory Stimulation-Euphoria; $\mathrm{AUC}_{\infty}=$ area under the concentration-time curve extrapolated to infinity; $\mathrm{AUC}_{\text {last }}=$ area under the concentration-time curve $0 \mathrm{~h}$ post-dose to last sample collection; $\mathrm{C}_{\max }=$ maximum plasma concentration; $\mathrm{HCl}=$ hydrochloride; LSD = lysergic acid diethylamide; MBG = Morphine-Benzedrine group; MSS = morphine sulfate solution; MS-sNTC = pellets within MS-sNT capsules taken crushed; MS-sNTW = MS-sNT capsules taken whole; NS = naltrexone $\mathrm{HCl}$ solution; $\mathrm{PK}=$ pharmacokinetic; $\mathrm{T}_{\max }=\operatorname{me}_{-}$ dian time to peak concentration; ULN = upper limit of normal; VAS = visual analog scale. 
Table 2. Study flow.

\begin{tabular}{|l|l|l|}
\hline $\begin{array}{l}\text { Naltrexone relative } \\
\text { bioavailability (29) }\end{array}$ & Oral drug liking/euphoria (32) & 12-Month safety (34) \\
\hline 24 participants enrolled & 132 participants screened & 467 participants enrolled \\
\hline $\begin{array}{l}1 \text { participant (4\%) discontinued } \\
\text { because of positive urine drug } \\
\text { screen result }\end{array}$ & 73 participants eligible; 59 ineligible & $\begin{array}{l}465(99.6 \%) \text { participants received } \geq 1 \text { dose of MS-sNT; } \\
\text { participants (0.4\%) not treated with MS-sNT }\end{array}$ \\
\hline 23 participants (96\%) completed & $\begin{array}{l}58 \text { participants randomized and treated in } \\
\text { qualifying session }\end{array}$ & $\begin{array}{l}305 \text { participants (65.3\%) discontinued: } \\
\text { AEs, 110 (23.6\%); noncompliance, } 64(13.7 \%) ; \\
\text { participant withdrew, 51 (10.9\%); lack of efficacy, } \\
39(8.4 \%), \text { lost to follow-up, 28 (6.0\%); other, 13 (2.8\%) }\end{array}$ \\
\hline & $\begin{array}{l}43 \text { participants passed screening/qualifying } \\
\text { period; 15 participants excluded from the study }\end{array}$ & $\begin{array}{l}160 \text { participants (34.3\%) completed 12 months MS-sNT } \\
\text { treatment. 124 participants completed the study. }\end{array}$ \\
\hline & $\begin{array}{l}32 \text { participants randomized, treated in the } \\
\text { treatment period. Completed all treatment } \\
\text { sessions and follow-up }\end{array}$ & 93 participants participated in PK subset evaluation \\
\hline
\end{tabular}

$\mathrm{AE}=$ adverse event; $\mathrm{PK}=$ pharmacokinetic.

\section{Naltrexone Relative Bioavailability Study}

The naltrexone relative bioavailability study (ALO01-07-104) evaluated the bioavailability of plasma naltrexone when pellets from a $60 \mathrm{mg}$ capsule of MS-sNT were crushed (MS-sNTC) for at least 2 minutes with a mortar and pestle relative to an oral solution containing the same dose of naltrexone as found in the sequestered core of MS-sNT capsule pellets (2.4 mg) (29). An analysis of variance model was used to compare maximum plasma concentration $\left(C_{\max }\right)$ and area under the concentration-time curve extrapolated to infinity $\left(A \cup C_{\infty}\right.$ ) among treatment groups (29). Equivalent bioavailability was established if $90 \%$ confidence intervals (Cls) for ratios of the log-transformed geometric means (In $\left[\mathrm{C}_{\max }\right]$ and In [AUC $C_{\infty}$ ]) fell within $80 \%$ to $125 \%(29,35,36)$.

\section{Oral Pharmacodynamic Study}

The oral pharmacodynamic study (ALO-01-07-205; NCT00751478) assessed the effects of naltrexone released from MS-sNTC and MS-sNT capsules taken whole (MS-sNTW; 2 MS-sNT capsules each containing $60 \mathrm{mg}$ extended-release morphine and $2.4 \mathrm{mg}$ naltrexone) on pharmacokinetic and drug liking/euphoria properties versus $120 \mathrm{mg}$ of MSS and placebo (32). Recreational opioid users received 4 treatments, one per session, with each session separated by a washout period of 14 to 21 days (32). Outcome measures included the determination of drug liking using a visual analog scale (VAS; $0=$ strong disliking, $50=$ neutral, $100=$ strong liking) and euphoria using the Cole/Addiction Research Center Inventory Stimulation-Euphoria scale (Cole/ARCI, 15 items, 4-point scale; 0 = false, 3 = true; score range, 0 to $45)$, as well as measurements of plasma morphine, naltrexone, and 6- $\beta$-naltrexol concentrations $(32,37)$.

\section{Twelve-Month Open-Label Safety Study}

The 12-month study (ALO-KNT-302, NCT00415597), while designed to examine the long-term, open-label safety of MS-sNT in patients with chronic, moderateto-severe pain, incorporated specific assessments of the potential impact of sequestered naltrexone (34). Safety assessments included the recording of adverse events (AEs), vital signs, clinical laboratory evaluations, and electrocardiograms (ECGs) (34). The Clinical Opiate Withdrawal Scale (COWS) was used to detect signs of opioid withdrawal $(34,38)$; COWS scores gave an indication of withdrawal severity ( 5 to 12 , mild; 13 to 24 , moderate; 25 to 36 , moderately severe; and $>36$, severe) $(34,38)$. Notably, hepatic enzymes alanine aminotransferase (ALT) and aspartate aminotransferase (AST) were specifically monitored because of previous reports of hepatotoxicity associated with naltrexone doses higher (50 to $300 \mathrm{mg}$ ) than those used clinically for opioid blockade $(34,39)$. Blood samples for pharmacokinetic analysis were collected at each visit from a subset of patients $(n=93)$ prior to dosing at 4-week intervals for the 52-week duration of the study (14 or fewer total samples per patient) $(34,40,41)$.

Efficacy assessments, as a prespecified secondary outcome, also were conducted in the 12-month study. Pain intensity was rated using an 11-point numeric scale ( $0=$ no pain, $10=$ pain as bad as you can imagine) 
along with a global assessment of the study drug using a 5 -point scale ( 1 = poor, 5 = excellent) (34).

\section{Pharmacokinetic Analysis}

In each study, blood samples for plasma morphine, naltrexone, and 6- $\beta$-naltrexol were prepared for pharmacokinetic analysis as described previously $(29,32,34)$. Bioanalysis was performed at CEDRA Corporation (Austin, TX) for the measurement of plasma naltrexone, 6 - $\beta$-naltrexol, and morphine using validated bioanalytical methods (liquid chromatography with tandem mass spectrometry); the lower limits of quantification were $4.00 \mathrm{pg} / \mathrm{mL}$ (naltrexone), $0.250 \mathrm{pg} / \mathrm{mL}$ (6- $\beta$-naltrexol), and $0.200 \mathrm{ng} / \mathrm{mL}$ (morphine) $(29,32,34)$.

\section{Results}

\section{Naltrexone Relative Bioavailability Study}

Mean plasma naltrexone concentration profiles appeared similar following single-dose administrations of MS-sNTC and naltrexone solution (Fig. 1A) (29). Both profiles exhibited rapid absorption, reaching peak concentrations of $599 \pm 408 \mathrm{pg} / \mathrm{mL}$ and $629 \pm 439 \mathrm{pg} / \mathrm{mL}$, respectively, at approximately one hour post-dose, followed by a biphasic elimination that was initially rapid to approximately 8 hours post-dose and then gradually declined to 24 hours post-dose (Table 3) (29).

Based on the extent of naltrexone absorption and overall naltrexone exposure, MS-sNTC exhibited similar bioavailability to naltrexone solution $(90 \% \mathrm{Cls}$ for plasma naltrexone In $\left[\mathrm{C}_{\max }\right]$ and In $\left[A \cup C_{\infty}\right]$ ratios were within the $80 \%$ to $125 \%$ range) (Table 3$)(29,35,36)$. The analysis of variance also was performed on a subset of participants that excluded those who vomited; the $90 \%$ Cls for plasma naltrexone In $\left(C_{\max }\right)$ and In $\left(A \cup C_{\infty}\right)$ ratios remained within the $80 \%$ to $125 \%$ range (29).

Over the duration of the blood sampling interval, the dispositions of 6 - $\beta$-naltrexol in plasma were similar after MS-sNTC and naltrexone solution singledose administrations (Fig. 1B): plasma naltrexone was rapidly converted to 6- $\beta$-naltrexol, reaching maximum concentrations at approximately 1.5 hours post-dose, and then gradually declined (29). The rate, extent, and total systemic exposure of 6- $\beta$-naltrexol from MS-sNTC and naltrexone solution showed equivalent bioavailability $\left(90 \%\right.$ Cls for plasma of $6-\beta$-naltrexol In $\left[C_{\max }\right]$ and

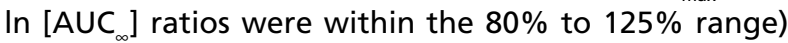
(Table 3) $(29,35,36)$.

After the administration of MS-sNTW, intact as directed, plasma concentrations of naltrexone were below the limit of quantification (BLQ) for nearly all participants. One participant had a single plasma naltrexone concentration of $5.50 \mathrm{pg} / \mathrm{mL}$ (just above the $4.00 \mathrm{pg} / \mathrm{mL}$ limit of quantification) at 72 hours post-dose (29). Low but quantifiable concentrations of plasma 6- $\beta$-naltrexol were observed for 14 of $23(60.9 \%)$ participants up to 168 hours post-dose (Fig. 1C) (29); 6- $\beta$-naltrexol mean concentrations never exceeded $5.00 \mathrm{pg} / \mathrm{mL}$ at any of the times evaluated for MS-sNTW (Fig. 1C) (29).

Of 89 treatment-emergent AEs reported during the study in 15 of 24 (63\%) participants, 87 (97.8\%) were mild and $2(2.2 \%$, nausea and emesis after intact MS-sNT) were moderate. The most common AEs in crushed, intact, and naltrexone treatment groups were nausea (8/23 [35\%], 10/24 [42\%], and 3/23 [13\%]) and emesis (6/23 [26\%], 7/24 [29\%], and $2 / 23$ [9\%]), respectively (29).

\section{Oral Pharmacodynamic Study}

Mean plasma morphine profiles after taking MSsNTC and MSS were similar (Fig. 2A), including plasma morphine mean $C_{\max }$ and median time to peak concentration $\left(T_{\text {max }}\right.$ ) (MS-sNTC, $80.6 \mathrm{ng} / \mathrm{mL}, 1.1$ hours; MSS, 92.5 ng/mL, 1.2 hours) $(32,41)$. Peak plasma morphine concentrations were reached at approximately one hour post-dose followed by biphasic elimination.

The disposition of plasma morphine following a single oral administration of MS-sNTW distinctly differed from the dispositions of MS-sNTC and MSS: the rate of absorption was slower, characteristic of the extended-release properties of the formulation, with peak concentrations reached at approximately 6 hours post-dose followed by a gradual rate of decline (32). $C_{\max }$ for MS-sNTW was lower (mean $C_{\max } 19.3$ versus 80.6 $\mathrm{ng} / \mathrm{mL}$ ) and $\mathrm{T}_{\max }$ was longer (median $\mathrm{T}_{\text {max }}, 8.1$ versus 1.1 hours) than those for MS-sNTC (Table 4) $(32,41,42)$.

Plasmanaltrexoneconcentrationsfollowing asingledose administration of MS-sNTC are shown in Fig. 2B. As expected, the disposition pattern of plasma naltrexone was similar to that of the MS-sNTC and naltrexone solution treatments in the naltrexone relative bioavailability study (29). The naltrexone $C_{\max }$ for MS-sNTC was $1,265.3 \mathrm{pg} / \mathrm{mL}$ with a median $\mathrm{T}_{\text {max }}$ of 1.1 hours (Table 4). However, low but quantifiable naltrexone concentrations were detected in 5 of 32 participants treated with MS-sNTW. Each of these 5 participants had one concentration above the limit of quantification $(4.00 \mathrm{pg} / \mathrm{mL})$, with the maximum being $44.8 \mathrm{pg} / \mathrm{mL}$ (32). 
$\boldsymbol{A}$

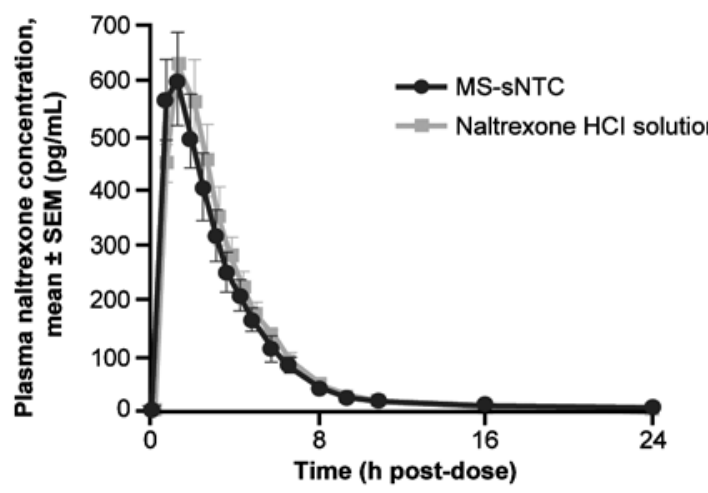

B

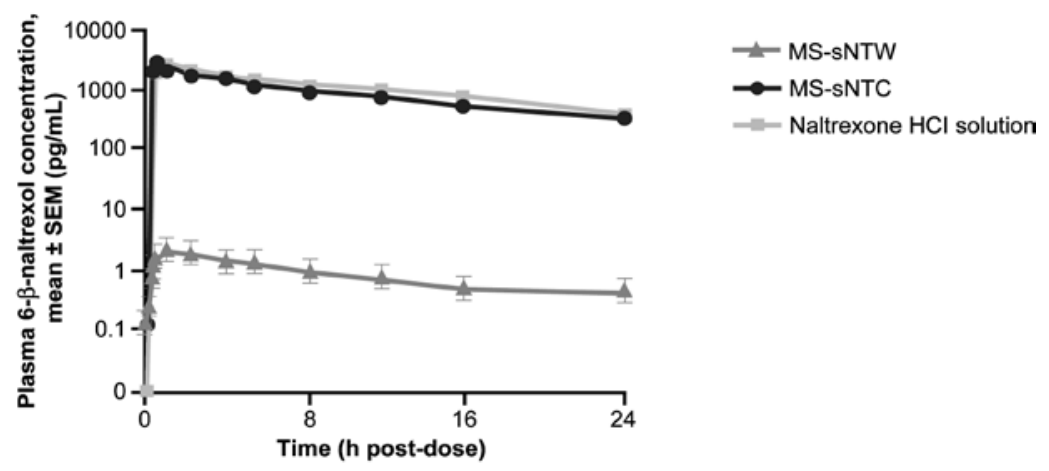

C

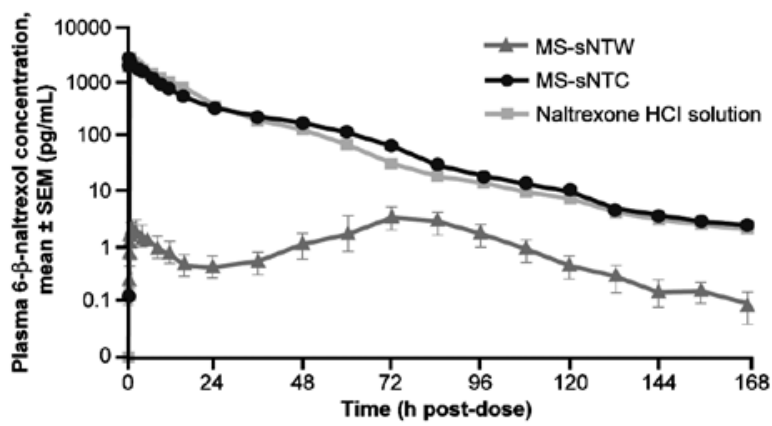

Fig. 1. Naltrexone relative bioavailability study: mean naltrexone ( $A$ ) and 6- $\beta$-naltrexol ( $B$ and $C$ ) concentration-time profiles (29).

$\mathrm{HCl}=$ hydrochloride; MS-sNTC = pellets within MS-sNT capsules taken crushed; MS-sNTW = MS-sNT capsules taken whole; SEM = standard error of the mean.

Adapted with permission from Johnson FK et al. Relative oral bioavailability of morphine and naltrexone derived from crushed morphine sulfate and naltrexone hydrochloride extended-release capsules versus intact product and versus naltrexone solution: A singledose, randomized-sequence, open-label, three-way crossover trial in healthy volunteers. Clin Ther 2010; 32:1149-1164 (29). 
Table 3. Naltrexone relative bioavailability study: pharmacokinetic summary (29).

\begin{tabular}{|c|c|c|c|}
\hline & \multicolumn{2}{|c|}{ Treatment $^{\mathrm{a}}$} & \multirow{2}{*}{$\begin{array}{c}\text { ANOVA results } \\
\text { Mean ratio }^{\mathrm{d}} \\
(90 \% \mathrm{CIs})\end{array}$} \\
\hline Parameter & MS-sNTC & NS & \\
\hline \multicolumn{4}{|l|}{ Plasma naltrexone } \\
\hline $\mathrm{C}_{\max }{ }^{\mathrm{b}}(\mathrm{pg} / \mathrm{mL})$ & $579(62.8)$ & $584(62.3)$ & $98.5(83.8,115.9)$ \\
\hline $\mathrm{T}_{\max }{ }^{\mathrm{c}}(\mathrm{h})$ & $1.00(0.50-2.00)$ & $1.00(0.50-2.00)$ & \\
\hline $\mathrm{AUC}_{\text {last }}^{\mathrm{b}}(\mathrm{pg} \cdot \mathrm{h} / \mathrm{mL})$ & $1,811(61.2)$ & $1,954(57.6)$ & $92.3(83.3,102.1)$ \\
\hline $\mathrm{AUC}_{\infty}{ }^{\mathrm{b}}(\mathrm{pg} \bullet \mathrm{h} / \mathrm{mL})$ & $1,870(61.3)$ & $2,000(56.9)$ & $93.1(84.4,102.7)$ \\
\hline \multicolumn{4}{|l|}{ Plasma 6- $\beta$-naltrexol } \\
\hline $\mathrm{C}_{\max }^{\mathrm{b}}(\mathrm{pg} / \mathrm{mL})$ & $3,530(35.4)$ & $3,710(34.4)$ & $94.7(86.3,104.0)$ \\
\hline $\mathrm{T}_{\max }{ }^{\mathrm{c}}(\mathrm{h})$ & $1.00(0.50-2.00)$ & $1.00(0.50-2.53)$ & \\
\hline $\mathrm{AUC}_{\text {last }}^{\mathrm{b}}(\mathrm{pg} \cdot \mathrm{h} / \mathrm{mL})$ & $38,130(30.5)$ & $41,330(29.6)$ & $92.2(85.5,99.5)$ \\
\hline $\mathrm{AUC}_{\infty} \mathrm{b}^{\mathrm{b}}(\mathrm{pg} \cdot \mathrm{h} / \mathrm{mL})$ & $38,210(30.5)$ & $41,440(29.7)$ & $92.2(85.5,99.5)$ \\
\hline
\end{tabular}

${ }^{a} \mathrm{MS}$-sNTW is excluded from the table due to lack of quantifiable plasma naltrexone concentrations. ${ }^{\mathrm{b}} \mathrm{Geometric}$ mean (CV\%); ${ }^{\mathrm{c}} \mathrm{Median}$ (range); ${ }^{\mathrm{d}}$ Ratio (\%) = geometric mean (test)/geometric mean (reference).

$\mathrm{ANOVA}=$ analysis of variance; $\mathrm{AUC}_{\infty}=$ area under the concentration-time curve extrapolated to infinity; $\mathrm{AUC}_{\text {last }}=$ area under the concentrationtime curve $0 \mathrm{~h}$ post-dose to last sample collection; $\mathrm{C}_{\max }=$ maximum plasma concentration; $\mathrm{CI}=$ confidence interval; $\mathrm{CV}=$ covariance; $\mathrm{MS}$-sNTC $=$ pellets within MS-sNT capsules taken crushed; NS = naltrexone solution; $\mathrm{T}_{\max }=$ median time to peak concentration.

Similarly, plasma 6- $\beta$-naltrexol levels were present after MS-sNTC treatment but in much higher concentrations than plasma naltrexone (Fig. 2C); low but quantifiable concentrations of 6 - $\beta$-naltrexol were detected in 14 participants after MS-sNTW. The plasma 6- $\beta$-naltrexol $C_{\max }$ for MS-sNTW (12.1 pg/mL) was less than that for MS-sNTC $(6,958.4 \mathrm{pg} / \mathrm{mL})$ (Table 4) $(32,42)$.

Pharmacodynamic evaluations are shown in Fig. 3 (32). Relative to the higher maximum VAS drug liking scores following a single administration of MSS, $53.1 \%$ of participants had at least a $30 \%$ reduction in mean maximum effect $\left(E_{\text {max }}\right)$ following MS-sNTC (Fig. 3A). Relative to the mean $\mathrm{E}_{\max }$ following single-dose administration of MSS, $50 \%$ of participants had at least a $40 \%$ reduction in maximum Cole/ARCI Stimulation-Euphoria scores after MS-sNTC (42). Mean VAS scores for drug liking and Cole/ARCI Stimulation-Euphoria scores were significantly lower after MS-sNTC versus MSS $(P<0.001)$ (Table 4, Fig. 3B) (32). There was considerable individual variability in the degree of reduction in drug liking and Cole/ARCI Stimulation-Euphoria scores ranging between $10 \%$ and $50 \%$. Differences between MS-sNTC and MSS were observed for the other positive subjective effects, such as subjective (monetary) drug value and "feeling high." Scores for each of these subjective effects for MS-sNTC versus MS-sNTW were similar $(32,42)$.

All AEs reported were mild to moderate in intensity for both active drug and placebo groups. The most common AEs when participants received morphine were the typical morphine-associated effects of euphoric mood, pruritus, somnolence, emesis, and nausea (32). The most common AEs when participants received placebo were euphoric mood, headache, and somnolence (32).

\section{Open-label Safety Study}

Of 93 participants who received MS-sNTW for up to 12 months and participated in the pharmacokinetic substudy, $21(22.6 \%)$ had quantifiable (limit of quantification $=4.00 \mathrm{pg} / \mathrm{mL}$ ) concentrations of naltrexone. Of the 444 samples assayed for plasma naltrexone, only $49(11 \%)$ were above $4.00 \mathrm{pg} / \mathrm{mL}$ (range, 4.03 to 145 $\mathrm{pg} / \mathrm{mL}$ ); among these, the median concentration of naltrexone over all study weeks was $10.1 \mathrm{pg} / \mathrm{mL}(34,41)$. After assigning all BLQs to $0 \mathrm{pg} / \mathrm{mL}$, the overall mean plasma naltrexone concentration was $2.31 \mathrm{pg} / \mathrm{mL}$ (43). There was no evidence of naltrexone accumulation dur- 

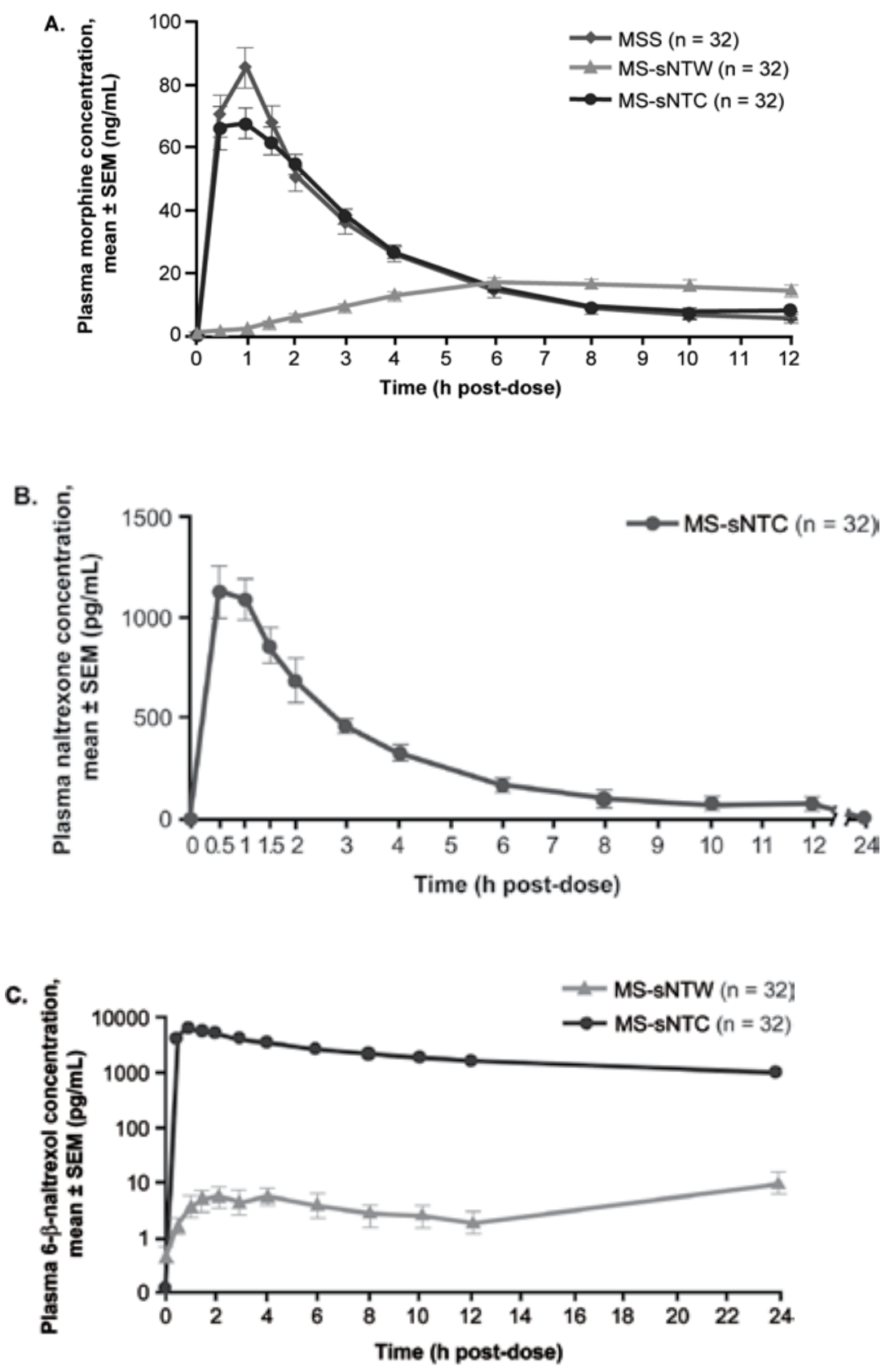

Fig. 2. Oral drug liking/euphoria study: morphine (A), naltrexone (B), and 6- $\beta$-naltrexol (C) concentration-time profiles (32).

MSS = morphine sulfate solution; MS-sNTC = pellets within MS-sNT capsules taken crushed; MS-sNTW = MS-sNT capsules taken whole; $\mathrm{SEM}=$ standard error of the mean

Adapted with permission from Stauffer J et al. Subjective effects and safety of whole and tampered morphine sulfate and naltrexone hydrochloride (ALO-01) extended-release capsules versus morphine solution and placebo in experienced non-dependent opioid users: A randomized, double-blind, placebo-controlled, crossover study. Clin Drug Investig 2009; 29:777-790 (32). 
Naltrexone Release, Pharmacodynamics, and Tolerability

Table 4. Oral drug liking/euphoria study: VAS drug liking; Cole/ARCI Stimulation-Euphoria; and plasma morphine, naltrexone, and 6- $\beta$-naltrexol across treatments $(32,41,42)$.

\begin{tabular}{|c|c|c|c|c|}
\hline \multirow[b]{2}{*}{ Outcome } & \multicolumn{4}{|c|}{ Treatment } \\
\hline & MS-sNTW & MS-sNTC & MSS & Placebo \\
\hline \multicolumn{5}{|c|}{ VAS for drug liking $(n=32)$} \\
\hline $\mathrm{E}_{\max }$, mean $(\mathrm{SD})$ & $67.6(13.1)$ & $68.1(17.5)^{\mathrm{b}}$ & $89.5(12.6)^{c}$ & $52.2(4.5)^{\mathrm{d}}$ \\
\hline $\mathrm{TE}_{\max }(\mathrm{h})$, median (range) & $8.00(0.50-12.0)$ & $2.00(0.48-24.0)$ & $1.49(0.48-24.0)$ & $1.50(0.48-8.00)$ \\
\hline $\mathrm{AUC}_{0-2 \mathrm{~h}}$, mean $(\mathrm{SD})$ & $79.1(14.5)$ & $86.7(23.4)$ & $120.7(20.9)$ & $74.5(6.60)$ \\
\hline $\mathrm{AUC}_{0-8 \mathrm{~h}}$, mean $(\mathrm{SD})$ & $405.9(62.4)$ & $424.3(128.6)$ & $519.7(140.6)$ & $375.5(33.7)$ \\
\hline \multicolumn{5}{|c|}{ Cole/ARCI Stimulation-Euphoria $(\mathrm{n}=32)$} \\
\hline $\mathrm{E}_{\max }$, mean $(\mathrm{SD})$ & $10.8(11.2)^{\mathrm{e}}$ & $11.9(11.3)^{\mathrm{b}}$ & $18.4(11.6)^{c}$ & $6.90(8.2)^{\mathrm{f}}$ \\
\hline $\mathrm{TE}_{\max }(\mathrm{h})$, median (range) & $1.75(0.48-24.0)$ & $1.50(0.48-24.0)$ & $1.00(0.48-24.0)$ & $1.00(0.48-24.0)$ \\
\hline $\mathrm{AUC}_{0-2 \mathrm{~h}}$ mean $(\mathrm{SD})$ & $9.6(12.4)$ & $14.0(14.9)$ & $26.2(18.8)$ & $8.8(12.5)$ \\
\hline $\mathrm{AUC}_{0-8 \mathrm{~h}}$, mean $(\mathrm{SD})$ & $44.0(53.5)$ & $56.8(69.5)$ & $84.7(68.9)$ & $32.5(47.2)$ \\
\hline \multicolumn{5}{|c|}{ Pharmacokinetics $(\mathrm{n}=32)$} \\
\hline \multicolumn{5}{|l|}{ Morphine } \\
\hline $\mathrm{C}_{\max }(\mathrm{ng} / \mathrm{mL})$, mean $(\mathrm{SD})$ & $19.3(7.68)$ & $80.6(38.8)$ & $92.5(38.1)$ & a \\
\hline $\mathrm{T}_{\max }(\mathrm{h})$, median (range) & $8.1(4.1-12.2)$ & $1.1(0.6-2.2)$ & $1.2(0.6-2.1)$ & a \\
\hline $\begin{array}{l}\mathrm{AUC}_{0-8 \mathrm{~h}}(\mathrm{ng} \cdot \mathrm{h} / \mathrm{mL}) \\
\text { mean }(\mathrm{SD})\end{array}$ & $80.7(42.2)$ & $259.7(90.7)$ & $262.6(92.8)$ & a \\
\hline $\begin{array}{l}\mathrm{AUC}_{\infty} \\
(\mathrm{ng} \bullet \mathrm{h} / \mathrm{mL}) \\
\text { mean (SD) }\end{array}$ & $427.2(327.4)$ & $480.7(330.1)$ & $362.6(119.5)$ & a \\
\hline \multicolumn{5}{|l|}{ Naltrexone } \\
\hline $\mathrm{C}_{\max }(\mathrm{pg} / \mathrm{mL})$, mean $(\mathrm{SD})$ & a & $1,265.3(706.3)$ & a & a \\
\hline $\mathrm{T}_{\max }(\mathrm{h})$, median (range) & a & $1.1(0.6-1.2)$ & a & a \\
\hline $\begin{array}{l}\mathrm{AUC}_{0-8 \mathrm{~h}}(\mathrm{pg} \cdot \mathrm{h} / \mathrm{mL}) \\
\text { mean }(\mathrm{SD})\end{array}$ & a & $3,943.8(1,927.8)$ & a & a \\
\hline $\begin{array}{l}\text { AUC }_{\infty} \\
(\mathrm{pg} \bullet \mathrm{h} / \mathrm{mL}) \\
\text { mean (SD) }\end{array}$ & a & $4,074.9(1,996.4)$ & a & a \\
\hline \multicolumn{5}{|l|}{ 6- $\beta$-Naltrexol } \\
\hline $\mathrm{C}_{\max }(\mathrm{pg} / \mathrm{mL})$, mean $(\mathrm{SD})$ & $12.1(14.7)^{\mathrm{g}}$ & $6,958.4(2,380.6)$ & a & a \\
\hline $\mathrm{T}_{\max }(\mathrm{h})$, median (range) & $2.7(0.6-24.2)$ & $1.1(0.6-2.1)$ & a & a \\
\hline $\begin{array}{l}\mathrm{AUC}_{0-8 \mathrm{~h}}(\mathrm{pg} \bullet \mathrm{h} / \mathrm{mL}) \\
\text { mean }(\mathrm{SD})\end{array}$ & $82.3(94.8)$ & $50,958.9(14,195.0)$ & a & a \\
\hline $\begin{array}{l}\mathrm{AUC}_{\infty} \\
(\mathrm{pg} \bullet \mathrm{h} / \mathrm{mL}) \\
\text { mean }(\mathrm{SD})\end{array}$ & $136.8(103.4)$ & $73,630.9(19,191.6)$ & a & a \\
\hline
\end{tabular}

${ }^{\text {aPK }}$ parameters could not be calculated due to lack of quantifiable drug concentrations.

${ }^{\mathrm{b}}$ Adjusted $P$ value not significant versus MS-sNTW.

cAdjusted $P<0.001$ versus MS-sNTC and MS-sNTW.

dAdjusted $P<0.001$ versus MS-sNTC, MS-sNTW, and MSS.

${ }^{\mathrm{e}}$ Adjusted $P$ value not significant versus placebo.

${ }^{\mathrm{f}}$ Adjusted $P<0.01$ versus MS-sNTC and MSS.

$\mathrm{g}_{\mathrm{n}}=14$.

$\mathrm{AUE}_{0-2 \mathrm{~h}}=$ area under the effect curve 0-2 h post-dose; $\mathrm{AUE}_{0-8 \mathrm{~h}}=$ area under the effect curve $0-8 \mathrm{~h}$ post-dose; $\mathrm{C}_{\max }=$ maximum plasma concentration; $\mathrm{E}_{\max }=$ maximum effect; MS-sNTC = pellets within MS-sNT capsules taken crushed; MS-sNTW = MS-sNT capsules taken whole; MSS = morphine sulfate solution; $\mathrm{SD}=$ standard deviation; $\mathrm{TE}_{\max }=$ time to reach the maximum effect; $\mathrm{T}_{\max }=$ time to peak concentration. 

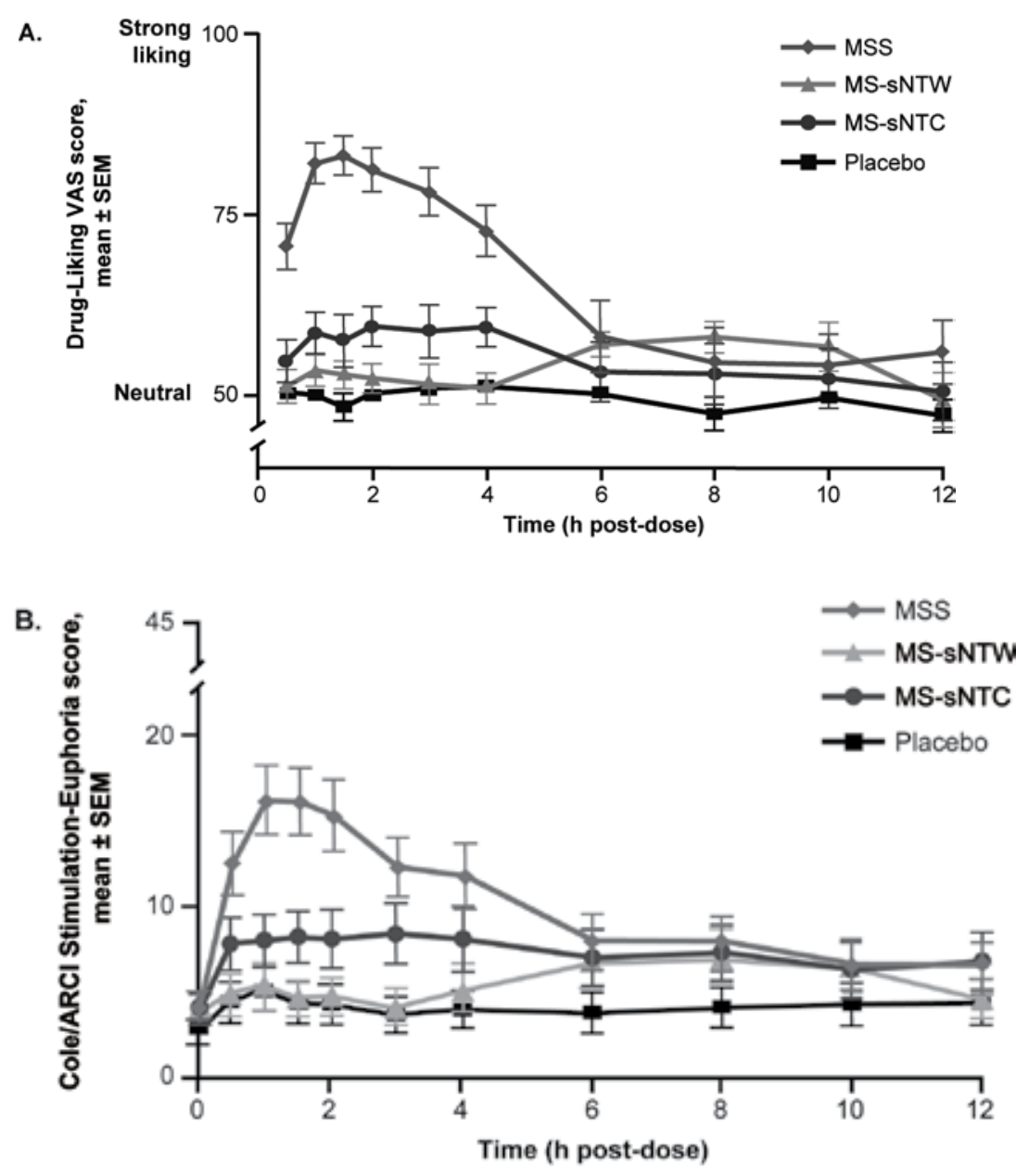

Fig. 3. Oral drug liking/euphoria study: pharmacodynamic measures (32).

ARCI = Addiction Research Center Inventory; MSS = morphine sulfate solution; MS-sNTC = pellets within MS-sNT capsules taken crushed; MS-sNTW = MS-sNT capsules taken whole; SEM = standard error of the mean; VAS = visual analog scale.

Adapted with permission from Stauffer J et al. Subjective effects and safety of whole and tampered morphine sulfate and naltrexone hydrochloride (ALO-01) extended-release capsules versus morphine solution and placebo in experienced non-dependent opioid users: A randomized, double-blind, placebo-controlled, crossover study. Clin Drug Investig 2009; 29:777-790 (32).

ing the study (Fig. 4), nor was there any significant correlation of plasma naltrexone concentration with MSsNT dosage, age, or sex of the participant $(34,41)$.

While participants were on the study drug, the mean change from baseline in all 4 pain diary items (average, least, worst, current) was significantly decreased from baseline except at week one for least pain (34). Overall, the percent change from baseline in average pain scores ranged from $-11.6 \%$ to $-41.5 \%$ throughout end-of-study treatment with MS-sNT (43).
Three participants had at least one outlying naltrexone concentration defined as a concentration outside of one standard deviation of the arithmetic mean (> $49.4 \mathrm{pg} / \mathrm{mL}$ ); however, these participants did not have increased COWS scores and pain intensity was not affected $(34,44)$. The highest naltrexone concentrations (145 and $118 \mathrm{pg} / \mathrm{mL}$ ) recorded in the study were observed at 20 and 32 weeks, respectively, for the same participant; corresponding COWS scores were 0 and 1 , respectively, and pain scores were 3 and 2, respectively 


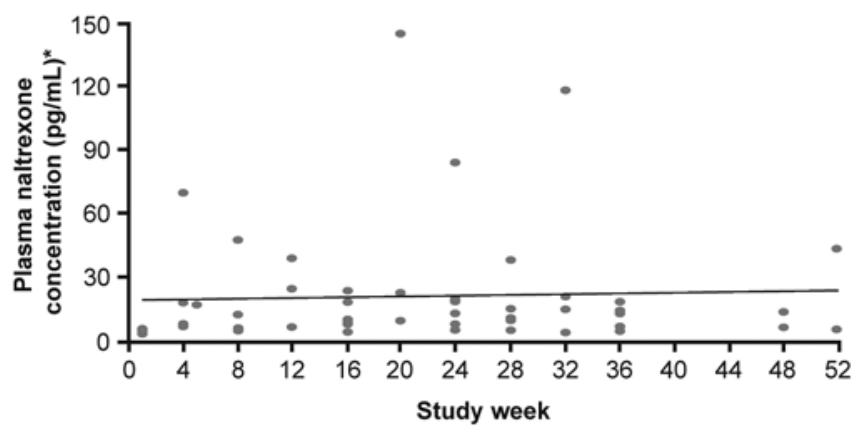

Fig. 4. 12-month safety study: individual plasma naltrexone concentrations over the duration of the study (41). ${ }^{\star}$ Includes only those patients with quantifiable levels.

Table 5. MS-sNT daily dose, COWS scores, and pain for patients with the highest plasma naltrexone concentrations $(34,44)$.

\begin{tabular}{|c|c|c|c|c|c|c||}
\hline \hline \multirow{2}{*}{ Patient } & $\begin{array}{c}\text { MS-sNT } \\
\text { average daily dose } \\
\text { (mg/day) }\end{array}$ & $\begin{array}{c}\text { Study } \\
\text { week }\end{array}$ & $\begin{array}{c}\text { Highest plasma } \\
\text { concentration } \\
\text { (pg/mL) }\end{array}$ & $\begin{array}{c}\text { Plasma morphine } \\
\text { concentration } \\
\text { (ng/mL) }\end{array}$ & CoWS score & $\begin{array}{c}\text { Pain } \\
\text { score }\end{array}$ \\
\hline \multirow{2}{*}{1} & 171 & 20 & 145.0 & 22.1 & 0 & 3 \\
\cline { 2 - 8 } & 185 & 32 & 118.0 & 40.9 & 1 & 2 \\
\hline 2 & 509 & 24 & 83.8 & 125.0 & 2 & 6 \\
\hline 3 & 800 & 4 & 69.7 & 118.0 & 3 & 0 \\
\hline 4
\end{tabular}

${ }^{a}$ The naltrexone concentration for this patient was not an outlier; data are included here because these were the only blood draws for plasma naltrexone determination available for this patient.

COWS $=$ Clinical Opiate Withdrawal Scale.

(Table 5) $(34,44)$. This participant was suspected of noncompliance (no detectable urine morphine concentrations were found) and was discontinued from the study (43). Another participant had naltrexone concentrations of 14.4 and $44.1 \mathrm{pg} / \mathrm{mL}$ at weeks 36 and 52, respectively (34). These naltrexone concentrations were not outliers, but were the only blood samples drawn from this participant for the determination of plasma naltrexone concentrations. The participant had poorly controlled pain: a pain score of 9 at baseline, lowest pain score of 5 at weeks 8 and 40, and the highest possible pain score of 10 at week 52 when plasma naltrexone concentration was $44.1 \mathrm{pg} / \mathrm{mL}$. The patient's corresponding COWS score at week 52 was $0(34,40)$.
During the 12-month treatment duration, mean COWS scores were low (Fig. 5). Fewer than $10 \%$ of patients had mild withdrawal at baseline and $\leq 5 \%$ had mild withdrawal at any study visit $(34,40)$. Only 5 participants had COWS scores consistent with moderate withdrawal; all 5 had not taken the study drug at the proper dose or according to the prescribed regimen. Violations included not taking the study drug or not taking the drug as instructed, adjusting own study dose, using incorrect dosing, reporting loss of the study drug, and running out of the study drug. None of these participants had elevated plasma naltrexone concentrations. Conversely, no participants with outlying plasma naltrexone concentrations during the study had COWS 


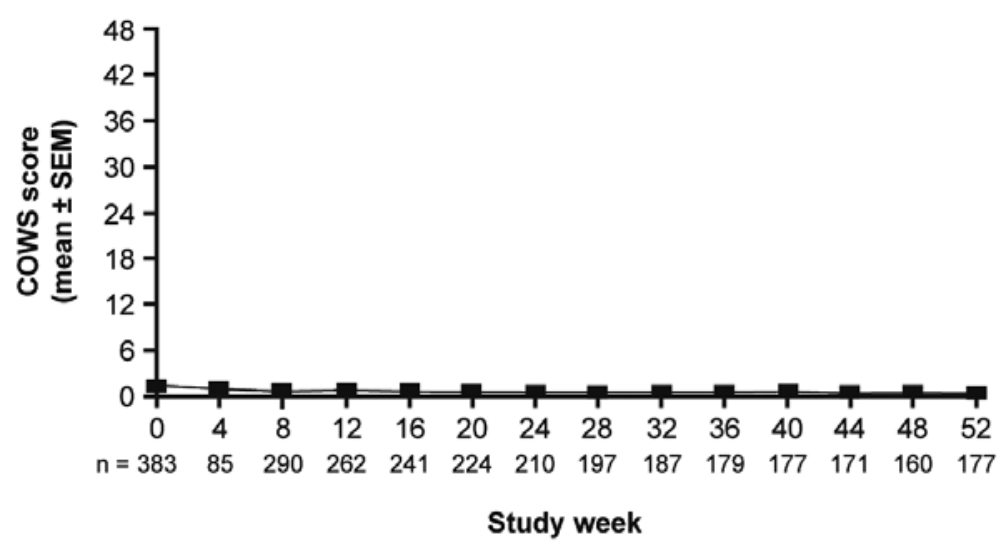

Fig. 5. Mean COWS scores over time (40).

COWS = Clinical Opiate Withdrawal Scale; SEM = standard error of the mean .

scores consistent with moderate withdrawal (34).

The most common AEs were those typically related to morphine use: constipation ( $n=148,31.8 \%$ ), nausea $(n=117,25.2 \%)$, headache $(n=56,12.0 \%)$, emesis ( $n=55,11.8 \%)$, and somnolence $(n=36,7.7 \%)(34,40)$. Most AEs were mild or moderate; $16.6 \%$ of participants had severe AEs, the most common being constipation, nausea, and headache (40). One participant had a clinically significant change from baseline in ECG (incomplete right bundle branch) that was judged by the investigator as unrelated to the study drug (34).

Four of the more than $\mathbf{4 0 0}$ participants in the study had moderately elevated liver function enzymes (ALT or AST) > 3x upper limit of normal (ULN) while taking MSsNT capsules (34). Participant 1 was a 59-year-old woman with a history of alcoholism who had an isolated elevation of AST (4.1x ULN) at 3 months; AST returned to normal despite increasing doses of MS-sNT $\leq 160 \mathrm{mg}$ $(34,43)$. She discontinued the study at 10 months $(34)$. Participant 2, a 60-year-old woman with a concomitant diagnosis of gastroenteritis, had elevated ALT (3.4x ULN), AST (2.0x ULN), and alkaline phosphatase (1.5x ULN) at 8.5 months after approximately 3 months of treatment with MS-sNT at $80 \mathrm{mg} / \mathrm{d}$. Her hepatic enzymes returned to normal when the MS-sNT dose was reduced to $40 \mathrm{mg} / \mathrm{d}$ (34). Participant 3 was a 49-year-old woman who discontinued the study due to nausea after fewer than 4 days of treatment with MS-sNT at 20 $\mathrm{mg} / \mathrm{d}$. She had elevated ALT (3.4x ULN) and AST (4.9x ULN) $(34,43)$. Participant 4, a 34-year-old woman who had a concomitant upper respiratory infection, had elevated ALT (3.9x ULN) at 6 days of treatment with MSsNT at $40 \mathrm{mg} / \mathrm{d}(34,43)$. The patient discontinued the study due to increasing shortness of breath, noncardiac chest pain, and nausea (34). Six additional participants had ALT values more than $2 x$ ULN at entry that normalized during the treatment period (34).

\section{Discussion}

Overall results from these 3 studies suggest that crushing MS-sNT provides an immediate release of naltrexone, making it available to mitigate morphineinduced subjective effects. In contrast, when MS-sNT is taken whole as directed, naltrexone remains sequestered in the majority of participants and in a 12-month safety study, did not accumulate, affect pain intensity, or precipitate withdrawal.

In the oral pharmacodynamic study, the release and subsequent absorption of a sufficient quantity of naltrexone from MS-sNTC decreased and delayed morphine-induced subjective effects versus those after immediate-release morphine for approximately $50 \%$ of participants with considerable individual variability (Table 4) (32). Pharmacodynamic effects with MS-sNTC were similar to those after intact MS-sNTW, suggesting that for nondependent abusers of opioids, tampering by crushing did not increase the drug liking or euphoria of MS-sNT in this study.

When MS-sNT was taken as directed by participants with chronic pain, the naltrexone remained sequestered 
as suggested by plasma naltrexone concentrations that were low or BLQ for most participants. Trace levels of 6 - $\beta$-naltrexol were present in most participants, indicating exposure to minimal concentrations of naltrexone; however, these concentrations did not appear to have any marked effect on precipitating opioid withdrawal. Although 6- $\beta$-naltrexol is a far less potent opioid antagonist than naltrexone (1/12th to $1 / 50$ th), its presence may contribute to the long duration of opioid antagonism of naltrexone $(20,26,27)$.

During up to 12 months of treatment with MSsNT, there was no evidence of accumulation of naltrexone and 6- $\beta$-naltrexol. Furthermore, results of the 12 -month safety study clearly showed that the low, but quantifiable, concentrations of plasma naltrexone and $6-\beta$-naltrexol did not adversely affect either the primary endpoint of safety or the secondary endpoint of efficacy of extended-release morphine sulfate. Most AEs were typical of those related to morphine rather than naltrexone, and there was a lack of symptoms related to opioid withdrawal (34). Pharmacokinetic results are consistent with early studies by Verebey et al $(26,27)$ showing almost identical plasma naltrexone concentrations after acute and chronic administration and an absence of the naltrexone and metabolites within 2 weeks of the discontinuation of chronic naltrexone administration.

The presence of naltrexone in MS-sNT had no negative impact on pain scores or clinical opioid withdrawal syndrome during long-term MS-SNT administration or in other clinical trials with EMBEDA $(31,45)$. No participant taking MS-SNT as directed in the 12-month safety study had COWS scores indicative of opioid withdrawal; 5 participants with COWS scores of 13 or higher, indicative of moderate withdrawal, had not taken the study drug at the proper dose or according to study instructions. In participants with the highest plasma naltrexone concentrations, there was no correlation with MSsNT daily dose, COWS scores, or pain intensity scores (34).

Although one participant had poorly controlled pain throughout the 12-month study and a maximum plasma naltrexone concentration of $44.1 \mathrm{pg} / \mathrm{mL}$ at the end of the study, there was no evidence of withdrawal symptoms (34). This participant could have been nonresponsive to opioid treatment. Another participant who had the highest plasma naltrexone concentration of $145 \mathrm{pg} / \mathrm{mL}$ had a corresponding COWS score of 0 and a pain score of $3(34,44)$.

Naltrexone doses of approximately $300 \mathrm{mg}$ have been reported to elevate serum transaminase enzymes 3 to 19 times baseline levels, especially in obese participants $(25,39)$. In the 12 -month safety study, hepatic enzymes in participants were increased to more than $3 x$ ULN in only 4 participants, 3 of whom had concomitant medical conditions; daily doses of MS-sNT in these participants ranged from 20 to $160 \mathrm{mg} / \mathrm{d}$ ( 0.8 to $4.8 \mathrm{mg}$ naltrexone). Two of these participants were included in the pharmacokinetic population; neither had increased naltrexone concentrations $(34,43)$.

In the 3 studies reported here, concentrations of naltrexone and $6-\beta$-naltrexol were an order of magnitude lower than those reported to be required for maximal human opioid occupancy (23) or to be present in plasma after the administration of doses used in a clinical setting (21). A dose-ranging study by Meyer et al (21) indicated that a $100 \mathrm{mg}$ dose of naltrexone hydrochloride resulted in mean ( \pm SD) plasma concentrations of $19.6( \pm 17.9) \mathrm{ng} / \mathrm{mL}$ of naltrexone and $206.8( \pm 78.1)$ $\mathrm{ng} / \mathrm{mL}$ of $6-\beta$-naltrexol, both reached at a mean $\mathrm{T}_{\max }$ of one hour. The few other published reports of naltrexone and 6- $\beta$-naltrexol plasma concentrations after naltrexone administration for opioid blockade support plasma concentrations in this range $(20,25-27)$. Using positron emission tomography scan methodology, the half maximal effective concentration for $90 \%$ occupancy of human central nervous system opioid receptors by naltrexone was estimated to be $1,600 \mathrm{pg} / \mathrm{mL}$ (23). These data suggest that, when MS-sNT is taken as directed, the exposure to naltrexone is too low to precipitate opioid withdrawal syndrome.

The 3 studies reported here were included in this review because during the clinical development program for MS-sNT, these studies used measures intended to examine the clinical effects of naltrexone within the MS-sNT formulation. Three additional studies briefly described below also included measurements of naltrexone levels. One was a pharmacokinetic study in 36 healthy volunteers assessing food effects on MS-sNT. Results indicated that naltrexone remained sequestered whether the product was consumed under fasting conditions, after consumption of a high-fat meal or sprinkled over apple sauce (46). The second was an open-label, randomized, single-dose, 4-way crossover, 4-sequence pharmacokinetic study in 32 healthy opioidnaiive adults that evaluated the effects of administering MS-sNT with increasing doses of alcohol on morphine and naltrexone bioavailability. Results indicated that naltrexone remained adequately sequestered when MS-sNT was coadministered with $4 \%, 20 \%$, and $40 \%$ 
alcohol (47). The third was a randomized, double-blind, crossover study in participants with chronic pain of osteoarthritis of the hip or knee, with a primary objective of comparing steady-state pharmacokinetics of morphine between MS-sNT and an extended-release morphine sulfate (ERMS) product without sequestered naltrexone (KADIAN [morphine sulfate extended-release] Capsules, Actavis Kadian LLC, US, Morristown, NJ). The study included a titration period with ERMS, followed by measurement of naltrexone levels in patients $(n=$ 72) on treatment days 1, 7, and 14 of a 2-week (crossover) treatment with MS-sNT and ERMS. Results indicated trace exposure to naltrexone and 6- $\beta$-naltrexol. The study did not include assessments of the effects of potential naltrexone exposure, such as evidence of opioid withdrawal. However, in cases where naltrexone and 6- $\beta$-naltrexol were quantifiable, it was noted that there was no positive correlation toward increased pain. AEs were similar during the 2-week treatment periods when the participants were either taking MS-sNT or ERMS $(31,48)$.

The 3 reviewed studies have several limitations: they were performed in healthy volunteers; recreational, nondependent opioid abusers; and selected patients with chronic, moderate-to-severe pain, and may not demographically reflect typical patients with chronic pain in a clinical setting or those with concomitant conditions $(29,32,34)$. The 12 -month study was not randomized and was open-label with no comparator (34).

The MS-sNT formulation was designed to address administration of the product when tampered with by crushing. Abusers of opioids may use a variety of methods to access, extract, and solubilize the drug for administration by various routes (e.g., intranasally or intravenously), and we have not studied other methods of tampering with MS-sNT or other routes of administration because some of the practices used by drug abusers are risky and cannot be evaluated safely in clinical studies. A recent study of intravenous administration of morphine alone and in combination with intravenous naltrexone found the morphine-naltrexone combination to yield reduced drug liking and euphoria in nondependent recreational opioid users compared with morphine alone (49). It should be noted that the studies in which crushed product was administered were conducted in non-opioid-dependent individuals $(32,49)$ where precipitation of opioid withdrawal would not have been expected. In 2 recently published case reports, opioid-tolerant patients who had tampered with MS-sNT capsules by either crushing or chewing had experienced signs and symptoms of withdrawal. In both cases, patients were admitted for treatment and symptoms had resolved $(50,51)$. This indicates that inappropriate use by tampering may result in withdrawal symptoms in opioid-tolerant individuals.

\section{Conclusions}

When pellets from MS-sNT capsules are crushed, the sequestered naltrexone is released and is immediately available to mitigate morphine-induced effects. The naltrexone released upon tampering with MS-sNT capsules decreased and delayed drug liking and euphoria in nondependent, recreational drug users. As demonstrated in 2 recent case examples, tampering with MSsNT capsules by crushing and/or chewing may result in precipitated withdrawal in opioid-tolerant individuals. When MS-sNT was taken as directed, plasma naltrexone was low or BLQ and did not accumulate over long-term use or precipitate opioid withdrawal symptoms.

\section{Disclosures}

Author Contributions: Both authors initiated and contributed to the concept, planning, drafting, revisions, and final approval of the article and had full knowledge of and access to study data. In addition, Mr. Johnson was involved in the study design, analysis, and interpretation of the data for all 3 of the studies included in the manuscript and was an author of the primary publications. Dr. Setnik was responsible for protocol development and implementation, study assessments, data entry and transfer, and analysis and interpretation of the data for the pharmacodynamic study; was an author of one of the primary publications; and provided critical analysis of the data from the other 2 studies included in this publication.

Conflict of Interest: Mr. Johnson is an employee of ClinPharm PK Consulting LLC, Bridgewater, NJ, and a former employee of and held stock in Alpharma Pharmaceuticals LLC, a wholly owned subsidiary of King Pharmaceuticals, Inc, which was acquired by Pfizer Inc in March 2011. Mr. Johnson is a co-inventor of the EMBEDA technology. Dr. Setnik is a former employee of DecisionLine Clinical Research Corporation, Toronto, Ontario, and of King Pharmaceuticals, Inc, which was acquired by Pfizer Inc in March 2011. At Pfizer Inc, Dr. Setnik is Director of Medical Development, Neurosciences. The authors did not receive any additional remuneration, reimbursement, or honoraria for writing this manuscript.

Funding/Support: The study was sponsored byAl- 
pharma Pharmaceuticals LLC, a wholly owned subsidiary of King Pharmaceuticals, Inc, which was acquired by Pfizer Inc in March 2011.

Editorial and medical writing support was provided by Carol Berry and Jessica Uychich of Quintiles Medical Communications, Parsippany, NJ, in close collaboration with the authors. Funding for editorial and medical writing support was provided by King Pharmaceuticals, Inc, Bridgewater, NJ, which was acquired by Pfizer Inc in March 2011.

Role of Sponsor: The financial sponsor of this work also provided financial support for the research reported and contributed to the study design and analysis and interpretation of the data.

\section{References}

1. Chou R, Fanciullo GJ, Fine PG, Adler JA, Ballantyne JC, Davies P, Donovan MI, Fishbain DA, Foley KM, Fudin J, Gilson AM, Kelter A, Mauksop A, O'Connor PG, Passik SD, Pasternak GW, Portenoy RK, Rich BA, Roberts RG, Todd KH, Miaskowski C. Opioid treatment guidelines. Clinical guidelines for the use of chronic opioid therapy in chronic noncancer pain. J Pain 2009; 10:113-130.

2. Trescot AM, Helm S, Hansen $H$, Benyamin R, Glaser SE, Adlaka R, Patel $S$, Manchikanti L. Opioids in the management of chronic non-cancer pain: an update of American Society of the Interventional Pain Physicians' (ASIPP) Guidelines. Pain Physician 2008; 11:S5S62.

3. Gourlay GK. Sustained relief of chronic pain. Pharmacokinetics of sustained release morphine. Clin Pharmacokinet 1998; 35:173-190.

4. McCarberg $\mathrm{BH}$, Barkin RL. Long-acting opioids for chronic pain: Pharmacotherapeutic opportunities to enhance compliance, quality of life, and analgesia. Am J Ther 2001; 8:181-186.

5. Nicholson B. Responsible prescribing of opioids for the management of chronic pain. Drugs 2003; 63:17-32.

6. Gibofsky A, Barkin RL. Chronic pain of osteoarthritis: Considerations for selecting an extended-release opioid analgesic. Am J Ther 2008; 15:241-255.

7. Nicholson B, Passik SD. Management of chronic noncancer pain in the primary care setting. South Med J 2007; 100:1028-1036.

8. Sloan P, Babul N. Extended-release opioids for the management of chronic non-malignant pain. Expert Opin Drug Deliv 2006; 3:489-497.

9. Manchikanti L. National drug control policy and prescription drug abuse: Facts and fallacies. Pain Physician 2007; 10:399424 .
10. Kuehn BM. Opioid prescriptions soar: increase in legitimate use as well as abuse. JAMA 2007; 297:249-251.

11. Katz NP, Adams EH, Chilcoat H, Colucci RD, Comer SD, Goliber P, Grudzinskas C, Jasinski D, Lande SD, Passik SD, Schnoll SH, Sellers E, Travers D, Weiss R. Challenges in the development of prescription opioid abuse-deterrent formulations. Clin J Pain 2007; 23:648-66o.

12. Katz NP, Adams EH, Benneyan JC, Birnbaum HG, Budman SH, Buzzeo RW, Carr DB, Cicero TJ, Gourlay D, Inciardi JA, Joranson DE, Kesslick J, Lande SD. Foundations of opioid risk management. Clin J Pain 2007; 23:103-118.

13. Gagnon AM, Kahan M, Srivastava A. Opioid use and abuse: Is there a problem? Clin J Pain 2007; 23:661-662.

14. Compton WM, Volkow ND. Major increases in opioid analgesic abuse in the United States: Concerns and strategies. Drug Alcohol Depend 2006; 81:103-107.

15. Gershell L, Goater J. Making gains in pain. Nat Rev Drug Discov 2006; 5:889890.

16. Woolf CJ, Hashmi M. Use and abuse of opioid analgesics: Potential methods to prevent and deter non-medical consumption of prescription opioids. Curr Opin Invest Drugs 2004; 5:61-66.

17. Fudala PJ, Johnson RE. Development of opioid formulations with limited diversion and abuse potential. Drug Alcohol Depend 2006; 83 Suppl 1:S40-S47.

18. Wright C, Kramer ED, Zalman MA, Smith MY, Haddox JD. Risk identification, risk assessment, and risk management of abusable drug formulations. Drug Alcohol Depend 2006; 83:S68-S76.

19. Webster LR, Bath B, Medve RA. Opioid formulations in development designed to curtail abuse: Who is the target? Expert Opin Investig Drugs 2009; 18:255263.
20. Misra AL. Current status of preclinical research on disposition, pharmacokinetics, and metabolism of naltrexone. In: Willette RE, Barnett G (eds). Narcotic Antagonists: Naltrexone Pharmacochemistry and Sustained-Release Preparations. Rockville, MD: US Department of Health and Human Services (DHHS); 1981. NIDA Research Monograph 28, 132-146.

21. Meyer MC, Straughn AB, Lo MW, Schary WL, Whitney CC. Bioequivalence, doseproportionality, and pharmacokinetics of naltrexone after oral administration. J Clin Psychiatry 1984; 45:15-19.

22. Gold MS, Dackis CA, Pottash ALC, Sternbach $\mathrm{HH}$, Annitto WJ. Naltrexone, opiate addiction, and endorphins. Med Res Rev 1982; 2:211-246.

23. Wong DF, Ye W, Zhou Y, Brasic J, Alexan$\operatorname{der}$ M, Nanadi A, Lorenz T, Tollefson G. In vivo human opiate receptor occupancy of naltrexone: A dose-response analysis. Abstract presented at the 36th Annual Meeting of the Society for Neuroscience; October 14-18, 2006; Atlanta, GA.

24. Kaiko RF, Grandy RP, Reder RF, Goldenheim PD, Sackler RS. A bioequivalence study of oral controlled-release morphine using naltrexone blockade. J Clin Pharmacol 1995; 35:499-504.

25. Gonzalez J, Brogden RN. Naltrexone: A review of its pharmacodynamic and pharmacokinetic properties and therapeutic efficacy in the management of opioid dependence. Drugs 1988; 35:192213.

26. Verebey K. The clinical pharmacology of naltrexone: Pharmacology and pharmacodynamics. In: Willette RE and Barnett G. Naltrexone Pharmacochemistry and Sustained Release Preparations. Bethesda, MD: National Institute on Drug Abuse; 1980. Naltrexone: Research 
Monograph 28, 147-158.

27. Verebey K, Volavka J, Mule SJ, Resnick RB. Naltrexone: Disposition, metabolism, and effects after acute and chronic dosing. Clin Pharmacol Ther 1976; 20:315328.

28. Embeda [package insert]. Bristol, TN: King Pharmaceuticals, Inc; June 2009.

29. Johnson FK, Stark JG, Bieberdorf FA, Stauffer J. Relative oral bioavailability of morphine and naltrexone derived from crushed morphine sulfate and naltrexone hydrochloride extended-release capsules versus intact product and versus naltrexone solution: A single-dose, randomizedsequence, open-label, three-way crossover trial in healthy volunteers. Clin Ther 2010; 32:1149-1164.

30. Johnson F, Sun S, Stauffer J, Wagner G. Morphine release profile in a formulation containing polymer-coated extendedrelease morphine sulfate plus sequestered naltrexone [abstract]. J Pain 2008; (Abstract 757):S4O.

31. Katz N, Sun S, Johnson F, Stauffer J. ALO-O1 (morphine sulfate and naltrexone hydrochloride) extended release capsules in the treatment of chronic pain of osteoarthritis of the hip or knee: Pharmacokinetics, efficacy, and safety. J Pain 2010; 11:303-311.

32. Stauffer J, Setnik B, Sokolowska M, Romach $M$, Johnson F, Sellers E. Subjective effects and safety of whole and tampered morphine sulfate and naltrexone hydrochloride (ALO-OI) extended-release capsules versus morphine solution and placebo in experienced non-dependent opioid users: A randomized, double-blind, placebo-controlled, crossover study. Clin Drug Investig 2009; 29:777790.

33. Lipman AG, Jackson KC II. Opioid pharmacotherapy. In: Warfield CA, Bajwa $\mathrm{ZH}$ (eds). Principles and Practices of Pain Medicine and ed. McGraw-Hill, New York, NY, 2004, pp 583-600.

34. Webster LR, Brewer R, Wang C, Sekora $D$, Johnson F, Morris D, Stauffer J. Longterm safety and efficacy of morphine sulfate and naltrexone hydrochloride extended release capsules, a novel formulation containing morphine and sequestered naltrexone, in patients with chronic, moderate to severe pain. J Pain Symptom Manage 2010; 40:734-746.

35. US Department of Health and Human Services, Food and Drug Administration, Center for Drug Evaluation and Research (CDER). Guidance for industry: bioavailability and bioequivalence studies for orally administered drug products-general considerations. Accessed Aug. 12, 2010. www.fda.gov. March 2003; Revision 1. www.fda.gov/ downloads/Drugs/GuidanceComplianceRegulatoryInformation/Guidances/ ucmo70124.pdf

36. US Department of Health and Human Services, Food and Drug Administration, Center for Drug Evaluation and Research. Guidance for industry: statistical approaches to establishing bioequivalence. Accessed Aug. 12, 2010. www.fda.gov. January 2001. www.fda. gov/downloads/Drugs/GuidanceComplianceRegulatoryInformation/Guidances/ucmo70244.pdf

37. Cole JO, Orzack MH, Beake B, Bird M, Bar-Tal Y. Assessment of the abuse liability of buspirone in recreational sedative users. J Clin Psychiatry 1982; 43:6974.

38. Wesson DR, Ling W. The Clinical Opiate Withdrawal Scale (COWS). J Psychoactive Drugs 2003; 35:253-259.

39. ReVia [package insert]. Montvale, NJ: Barr Pharmaceuticals Inc.; July 2002.

40. Data on File. Study number: ALOKNT-302. Alpharma Pharmaceuticals LLC, a wholly owned subsidiary of King Pharmaceuticals, Inc, Bridgewater, NJ, which was acquired by Pfizer Inc in March 2011.

41. Johnson F, Stauffer J. Pharmacokinetics, drug-liking/euphoria, and long-term study of morphine sulfate and naltrexone hydrochloride extended release capsules. Poster presented at the Annual Meeting of the American Society for Clinical Pharmacology and Therapeutics; March 18-21, 2009; National Harbor, MD.

42. Data on File. Study number: ALO-O1-07205. Alpharma Pharmaceuticals LLC, a wholly owned subsidiary of King Pharmaceuticals, Inc, Bridgewater, NJ, which was acquired by Pfizer Inc in March 2011.

43. Alpharma Pharmaceuticals LLC. ALOo1 (morphine sulfate extended-release with sequestered naltrexone hydrochloride capsules) for the management of moderate to severe pain when a continuous, around-the-clock opioid analgesic is needed for an extended period of time: NDA open session briefing package. NDA-22-321. Meeting of the Anesthetic and Life Support Drugs Advisory Committee. FDA.gov. Novem- ber 14, 2008. Accessed Oct. 21, 2010. www.fda.gov/ohrms/dockets/AC/08/ briefing/2008-4395b2-02-ALPHARMA. pdf

44. Johnson F, Manning D, Wang C, Stauffer J. Evaluation of naltrexone concentrations following dosing with ALOor (morphine sulfate and naltrexone hydrochloride) extended release capsules for 1 year in patients with chronic pain. Poster presented at the 71st Annual Meeting of The College on Problems Drug Dependence; June 20-25, 2009; Reno, NV.

45. Katz N, Hale M, Morris D, Stauffer J. Morphine sulfate and naltrexone hydrochloride extended-release capsules in patients with chronic osteoarthritis pain. Postgrad Med 2010; 122:112-128.

46. Johnson F, Ciric S, Boudriau S, Swearingen D, Stauffer J. Food effects on the pharmacokinetics of morphine sulfate and naltrexone hydrochloride extended release capsules. Adv Ther 2010; 27:846858.

47. Johnson FK, Ciric S, Boudriau S, Kisicki J, Stauffer J. Effects of alcohol on the pharmacokinetics of morphine sulfate and naltrexone hydrochloride extended release capsules. J Clin Pharmacol In press.

48. KADIAN CII Capsules [package insert]. Morristown, NJ: Actavis Kadian LLC; February 2010.

49. Webster LR, Johnson FK, Stauffer J, Setnik B, Ciric S. Impact of intravenous naItrexone on intravenous morphine-induced high, drug liking, and euphoric effects in experienced non-dependent male opioid users. Drugs $R D$ 2011, in press.

50. Jang DH, Robe JC, Hoffman RS. Severe opioid withdrawal due to misuse of new combined morphine and naltrexone product (Embeda). Ann Emerg Med 2010; 55:303-304.

51. Ruan X, Chen T, Gudin J, Couch JP, Chiravuri $S$. Acute opioid withdrawal precipitated by ingestion of crushed Embe$\mathrm{da}$ (morphine extended release with sequestered naltrexone): Case report and the focused review of the literature. J Opioid Manag 2010; 6:300-303.

52. Data on File. Study number: ALO-O1-O7104. Alpharma Pharmaceuticals LLC, a wholly owned subsidiary of King Pharmaceuticals, Inc, Bridgewater, NJ, which was acquired by Pfizer Inc in March 2011. 